\title{
Resazurin Based Colorimetric Proliferation Assay for PBMCS of Goats and Sheep
}

\author{
Soumajit Sarkar*, Ashwini Rameshrao Chaple, Aruna Kuniyal, Dhanavelu \\ Muthuchelvan, Muthannan Andavar Ramakrishnan*
}

Division of Virology, ICAR-Indian Veterinary Research Institute, Mukteswar, Uttarakhand - 263 138, India,

*Corresponding author

\section{A B S T R A C T}

\begin{tabular}{|l|}
\hline Ke y w or d s \\
$\begin{array}{l}\text { Cell proliferation; } \\
\text { goat; sheep; } \\
\text { PBMCs; } \\
\text { Resazurin; BrdU }\end{array}$ \\
\hline Article Info \\
\hline $\begin{array}{l}\text { Accepted: } \\
\text { 08 January 2020 } \\
\text { Available Online: } \\
\text { 10 February 2020 }\end{array}$ \\
\hline \hline
\end{tabular}

Resazurin dye-based colorimetric assay is simple and cost-effective to evaluate viability and cytotoxicity. This dye also used for evaluating proliferative responses of PBMCs against mitogens and antigens especially to assess the CMI response against vaccines and pathogens. However, the assay needs to be optimized for different cell types and animal species. So far, resazurin based assay is not available for sheep and goats. In the present study, the assay was optimized for PBMCs of goat with two density gradients viz., Histopaque 1.077 and 1.083, and different culture conditions. The cell yield obtained through Histopaque 1.083 was 10.5 times more than cells obtained through 1.077. Out of three tested media, cells cultivated with TCM-199 showed the highest growth followed by RPMI-1640, and AIM-V. The resazurin dye @600 $\mu \mathrm{M}$ and $24 \mathrm{~h}$ dye reduction time yielded a better result. Among four mitogens tested PHA-P induced higher proliferation followed by ConA, PWM, and LPS. The result was correlated with the result obtained in the chemiluminescence based BrdU ELISA. Further, the resazurin assay also validated in sheep PBMCs.

\section{Introduction}

Cell-mediated immune response (CMI) is one of the major wings of immune responses that provide protection against various pathogens. Evaluation of CMI response is required for various research works including disease diagnosis and vaccines. Delayed type hypersensitivity test (DTH) is well known in vivo method to detect $\mathrm{CMI}$ responses whereas lymphocyte proliferation assay has been widely used in ex vivo.

The evaluation of CMI response broadly categorized into stimulation (leukocyte migration method), effector activity (cytokine kinetics), and cell proliferation activity (Nikbakht et al., 2019). 
To measure cell proliferation, various assays have been employed and these can be broadly classified into five major categories.

1) Nucleoside-analog incorporation assays where proliferation can be measured by the incorporation of radioactive tritiated thymidine $\left[{ }^{3} \mathrm{H}\right]$ (Brown, 1977; Duque and Rakic, 2011; Schultz, 1982).

Hazards and restrictions of handling radioactive substances limit the use of this labeling reagent and use of thymidine analog such as BrdU (5-bromo-2'-deoxyuridine) as a labeling reagent with monoclonal antibodybased detection system became more popular (Kuwagata et al., 2007; Romar et al., 2016).

2) Detection of cell cycle-associated proteins (topoisomerase II, phosphorylated histone H3) using immunofluorescence, immunohistochemistry and flow cytometry (Hans and Dimitrov, 2001) enables detection of cell division.

3) Use of cytoplasmic proliferation dyes such as carboxyfluorescein diacetate succinimidyl ester (CSFE) also enables detection of proliferative cell cytokinesis employing flow cytometric analysis (Quah and Parish, 2012; Romar et al., 2016).

4) Indirect measures of cell proliferation employ trypan blue cell viability (Strober, 2001), MTT/resazurin dye incorporation (Czekanska, 2011; Sylvester, 2011). 5) more recently, electrochemical monitoring of proliferation in cell culture, as well as whole blood using cyclic voltammetry, has been reported (Nikbakht et al., 2019). Each of these assays has its own merits and limitations.

Due to the simplicity and economical merits, many researchers prefer colorimetric assay to measure cell proliferation (Koyanagi et al.,
2016; Mosmann, 1983; Roehm et al., 1991). There are several dyes have been employed and MTT, XTT, and resazurin were most popular (Borra et al., 2009; Koyanagi et al., 2016; Roehm et al., 1991; Sylvester, 2011; Vega-Avila and Pugsley, 2011). Resazurin is preferred over other dyes due to its higher sensitivity and less toxicity (Czekanska, 2011).

This dye mainly used in human cells but it was not evaluated for sheep and goats so far. Therefore, in the current study, cell proliferation assay from peripheral blood mononuclear cells (PBMCs) of goat using resazurin and compared with monoclonal antibody-based BrdU chemiluminescence ELISA. The optimized protocol also evaluated with PBMCs of sheep.

\section{Materials and Methods}

\section{Isolation and culturing of PBMCs}

Goat PBMCs were isolated from whole blood using density gradient medium - Histopaque $1.083 \mathrm{~g} / \mathrm{mL}$ (Sigma, Cat. No. 10831). For comparison of the cell yield, Histopaque 1.077 was included. Two $\mathrm{mL}$ of whole blood was mixed in PBS (1:1), layered over Histopaque and centrifuged at $1000 \times \mathrm{g}$ for 30 minutes.

The PBMCs appearing at the junction between plasma and Histopaque were aspirated gently using a pipette. In order to remove residual RBCs, the cells were washed twice with ACK-RBC lysis buffer and centrifuged at $2000 \times \mathrm{g}$ for 5 minutes. The pelleted PBMCs were washed twice with PBS and resuspended in $1 \mathrm{~mL}$ of culture media.

The cell growth was assessed using three different media viz., AIM-V (Gibco, Cat. No. 12055091), TCM-199 (Gibco, Cat. No. 12340030) and RPMI-1640 (Sigma, Cat. 
No.R7755-10L). The media were supplemented with $1 \mathrm{mM}$ sodium pyruvate (Gibco, Cat. No. 11360070), $50 \mu \mathrm{M} 2$ mercaptoethanol (Amresco, Cat. No. 0482), antibiotic antimycotic solution (Gibco, Cat. No. 15240112), and 10\% horse serum (Gibco, Cat. No.16050114). The viability of the cells was measured using $0.4 \%$ trypan blue. The seeding concentration of PBMCs was optimized with different concentrations of cells $\left(10^{2}\right.$ to $10^{5} /$ well $)$.

Four different mitogens with various concentrations were evaluated: two $\mathrm{T}$ lymphocyte stimulatory mitogens [ConA Sigma, Cat. No. C2010), PHA-P (Sigma, Cat. No. L8754)], one B lymphocyte stimulatory mitogen (LPS; Sigma, Cat. No. L405) and one T and B lymphocyte stimulatory mitogen (PWM; Sigma, Cat. No. L9379).

The cells were seeded at a concentration of $10^{5}$ cells/well and stimulated with serial twofold diluted mitogens (from10 $\mu \mathrm{g} /$ well to $0.0710 \mu \mathrm{g} / \mathrm{well})$. Unstimulated cell control, as well as wells with only cell culture media, was also included.

\section{Resazurin based cell proliferation assay}

The concentration of resazurin (Sigma, Cat. No. R7017) was optimized by serial two-fold dilutions (1200 $\mu \mathrm{M}$ to $9.375 \mu \mathrm{M})$. To evaluate optimum dye reduction time, the dye was added at a rate of $10 \%$ culture volume $(10 \mu \mathrm{L})$ in each well and incubated at $37{ }^{\circ} \mathrm{C}$ for 4,6 , 9, 12, 24 and $48 \mathrm{~h}$.

The $\%$ dye reduction was calculated by taking $O D$ value at $570 \mathrm{~nm}$ with reference OD at 600 $\mathrm{nm}$ and applying the formula described elsewhere (Patel et al., 2013).

The assay optimized for the goat was also evaluated for sheep. However, mitogen concentrations were reoptimized for sheep PBMCs $(50 \mu \mathrm{g} /$ well to $0.39 \mu \mathrm{g} /$ well $)$.

\section{BrdU cell proliferation assay}

The optimized resazurin assay for PBMCs of the goat was compared with Chemiluminescent BrdU ELISA (Roche Cat. No. 11669915001). Briefly, isolated PBMCs were seeded at a density of $10^{5}$ cells/well with TCM-199 in a black clear bottom 96 well microtiter plate (Corning, Cat. No. 3603). The cells were added with two-fold serially diluted mitogens (goat- $10 \mu \mathrm{g} /$ well to 0.0710 $\mu \mathrm{g} /$ well).

Cells and BrdU were omitted to serve as blank and background control, respectively. The cells were incubated at $37{ }^{\circ} \mathrm{C}$ with $5 \%$ $\mathrm{CO}_{2}$ for $24 \mathrm{~h}$. Then the cells were labeled with BrdU $(10 \mu \mathrm{M})$ and incubated for further $24 \mathrm{~h}$. After that, the plates were centrifuged at $300 \mathrm{xg}$ for 10 minutes; labeling media was gently decanted and air-dried.

The remaining procedure carried out as per the guidelines provided in the kit. Luminescence was measured from the bottom of the microtiter plate at 460/40 emission wavelength with automatic gain adjustment of a standard luminescence measuring reader (Synergy $^{\text {TM }}$ HTX Multi-Mode Microplate Reader, BioTek).

Necessary approval was obtained from approved by Institutional Animal Ethics Committee, ICAR-Indian Veterinary Research Institute Mukteswar and the Committee for the Purpose of Control and Supervision of Experiments on Animals, New Delhi, India.

\section{Results and Discussion}

\section{Density gradient}

The yield of goat PBMCs obtained through Histopaque 1.083 and 1.077 was compared. The experiments were repeated seven times 
and found that Histopaque 1.083 is better than 1.077 in terms of cell yield. When using Histopaque 1.083, the average cell yield was $6.8 \times 10^{6}$ viable cells $/ \mathrm{mL}$ whereas it was 0.69 $\mathrm{x} 10^{6}$ in Histopaque 1.077. This represents 10.57 times more yield.

\section{Culture media}

Out of three media, higher growth was observed in cells grown in TCM-199 followed by RPMI, and AIM-V (Fig.1). The cells cultured in AIMV showed very poor growth with fewer numbers of cells. The cultured cells were round, refractile, large, and bright in nature.

\section{Resazurin and reduction time}

It was noted that seeding density of $10^{5}$ cells/well, $600 \mu \mathrm{M}$ concentration of resazurin and $24 \mathrm{~h}$ dye reduction time yielded optimum result i.e. at these concentrations the dye reduced significantly (Fig.2).

\section{Mitogens}

The optimum doses of mitogens were varied between PBMCs of goat and sheep. In goat PBMCs, maximum proliferation was obtained at $0.31 \mu \mathrm{g} /$ well $\left(0.31 \mu \mathrm{g}\right.$ for $10^{5}$ cells $)$ of
ConA, LPS, and PHA-P. PWM -induced maximum proliferation at $0.15 \mu \mathrm{g} /$ well. Similar results were obtained for both resazurin and BrdU ELISA (Fig.3).

In the case of sheep PBMCs, the optimum concentrations required for maximum proliferation by Con A, LPS, PHA-P and pokeweed were $6.25,3.12,0.78$ and $3.1 \mu \mathrm{g} / \mathrm{well}$, respectively.

In addition to the humoral response, cellmediated immune (CMI) response needs to be evaluated (Chaplin, 2010; Wing and Remington, 1977) for many research works. Although, evaluation of humoral response is relatively simple and easy to perform, assessing CMI response needs technical expertise and sophisticated equipment.

There are several techniques have been employed to assess the CMI responses in various humans and other animals (Sandbulte and Roth, 2004).

However, very few techniques have been used to assess the CMI response in sheep and goats. For example in vivo delayed-type hypersensitivity (DTH) reaction against PHA (Singh et al., 2015), and glucose utilization test (Bhanuprakash et al., 2004).
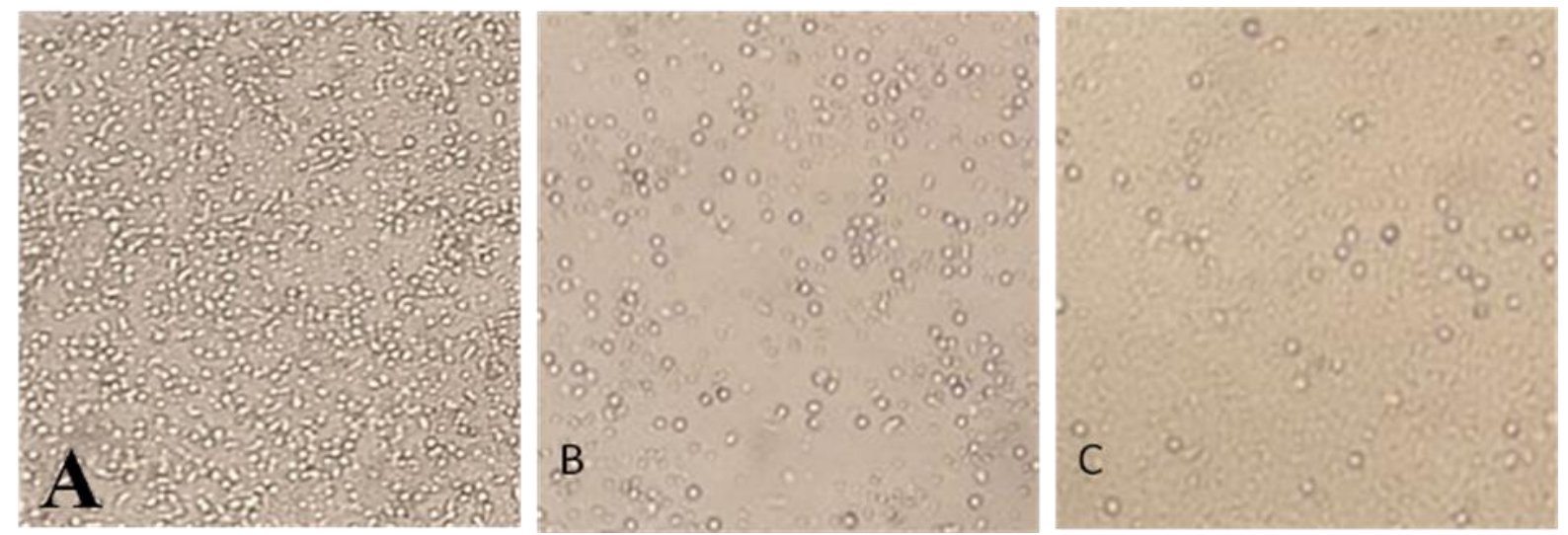

Fig. 1 The morphology of un-stimulated cultured goat PBMCs after $24 \mathrm{~h}$ of seeding in (A) TCM199, (B) RPMI-1640 and (C) AIM-V 

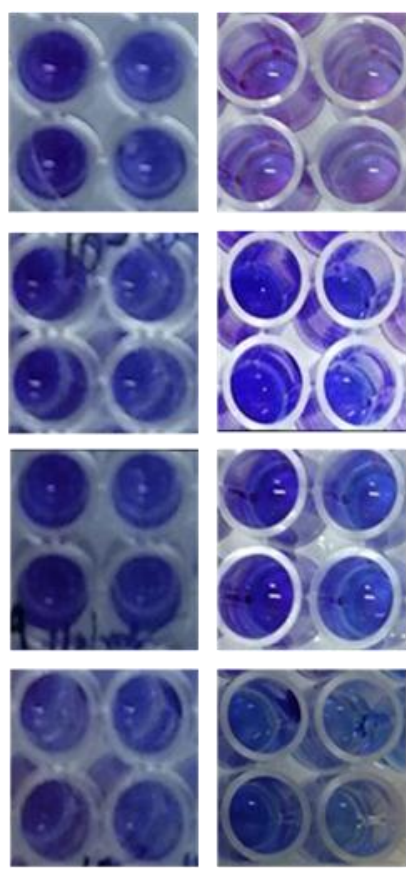

$4 \mathrm{~h}$
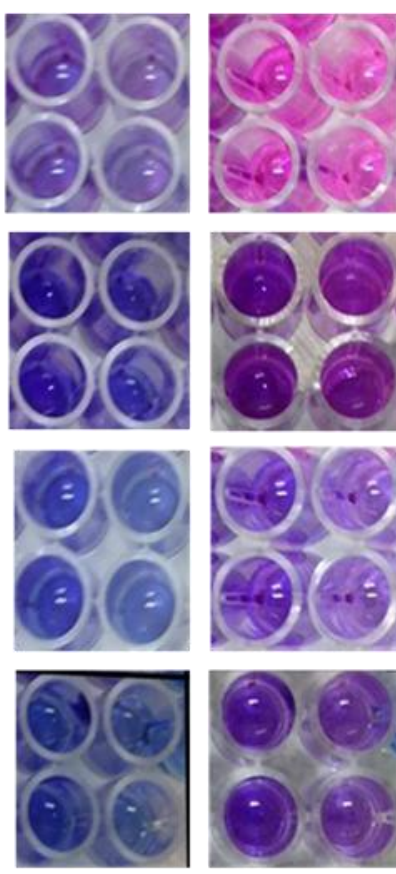

$9 \mathbf{h}$

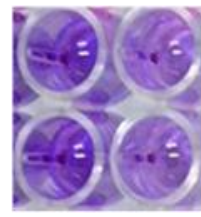

$12 \mathrm{~h}$
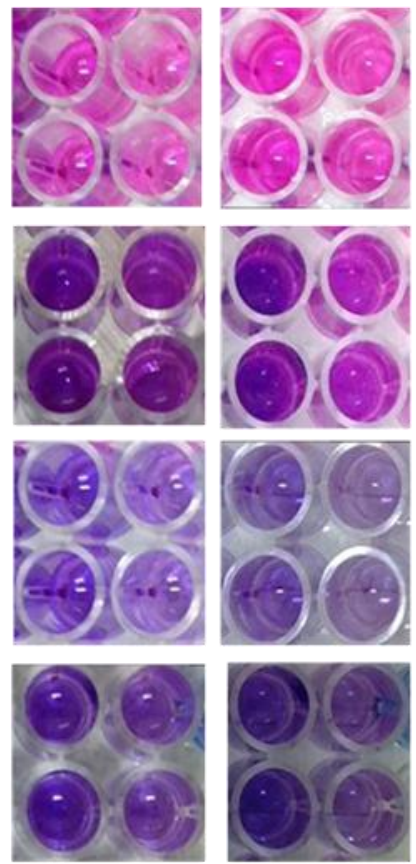

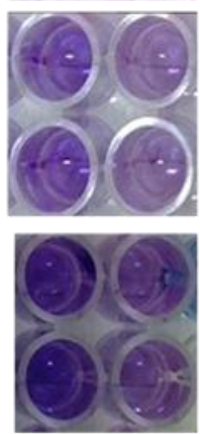

24 h

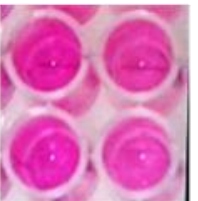

$10^{5}$ cells/well

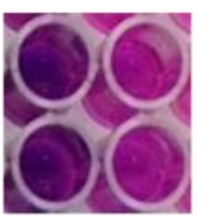

$10^{4}$ cells/well

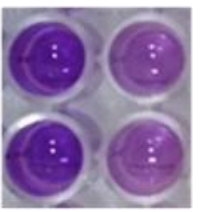

$10^{3}$ cells/well

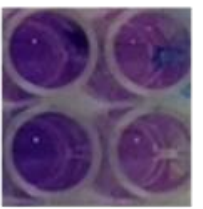

$10^{2}$ cells/well

Fig.2 Optimization of goat PBMCs seeding concentration and resazurin dye reduction time

One of the reliable, simple and economical methods is dye-based PBMCs proliferation assay (Borra et al., 2009; Czekanska, 2011; Koyanagi et al., 2016; Vega-Avila and Pugsley, 2011). The most commonly used dyes are MTT, XTT, WST-1 and resazurin.

MTT dye is toxic to cells and insoluble in water and may not accurately represent the changes in cell growth (Huang et al., 2017; Sylvester, 2011). XTT dye is more sensitive and less toxic than MTT but does not represent the accurate cellular proliferation picture. WST-1 dye is more sensitive than MTT and XTT with variable sensitivity (Aslantürk, 2018; Roehm et al., 1991).

Resazurin has advantages, including rapidity, reliability, sensitivity and less toxic than other dyes (Czekanska, 2011). In addition, it keeps cells intact, which permits other parallel analyses, such as mRNA, cytogenetic, apoptosis, and immune phenotyping (Zhi-Jun et al., 1997) to be conducted. However, this assay has not been evaluated so far in goats and sheep.

In our study, $24 \mathrm{~h}$ incubation period, and 600 $\mu \mathrm{M}$ of resazurin produced optimum dye reduction in goat PBMCs cultivated in TCM199 medium. The incubation time may vary between dye concentration, type of cells, number of cells, media used, etc. (Riss et al., 2004).

It was reported that $700 \mu \mathrm{M}$ resazurin and 11 to 19 hours of incubation period yielded the best result for human buccal fibroblast cell line (FLM1) cells. Further, the same concentration of dye with an incubation period of 6 to $10 \mathrm{~h}$ yielded the best result for L929, a murine tumor cell line (Borra et al., 2009). In our study, TCM-199 media yielded the best result for the proliferation of goat PBMCs when compared with RPMI-1640, and AIM-V. 
Further, supplementation of horse serum and 2-mercaptoethanol (2-ME) required for better proliferation (Gottshall and Hansen, 1994). Although, the mechanism of action of 2-ME is not fully understood it was reported that the addition of 2-ME partially restores the blastogenic activity from ConA induced depression in sheep PBMCs (Chan et al., 2002; Click, 2014; Fiscus et al., 1982).

Our result is in corroboration with the previous study in that TCM-199 yielded better proliferation in sheep PBMCs than RPMI1640 or AIM-V in the ${ }^{3} \mathrm{H}-\mathrm{Tdr}$ assay (Gottshall and Hansen, 1994).

The selection of mitogens and its dose depends on the species from which the
PBMCs are obtained (Norian et al., 2015). In goat PBMCs, PHA-P induced more proliferation followed by ConA, PWM and LPS.

The same results were obtained with both resazurin and BrdU assays. In sheep, the highest proliferation observed in PHA-P followed by PWM, ConA, and LPS in resazurin assay.

The mitogen concentration may vary between the cell type and species. In sheep also PHA-P yielded better proliferation than ConA. These results are in corroboration with other researchers who observed similar results in sheep PBMCs with ${ }^{3} \mathrm{H}-\mathrm{Tdr}$ assay (Gottshall and Hansen, 1994).
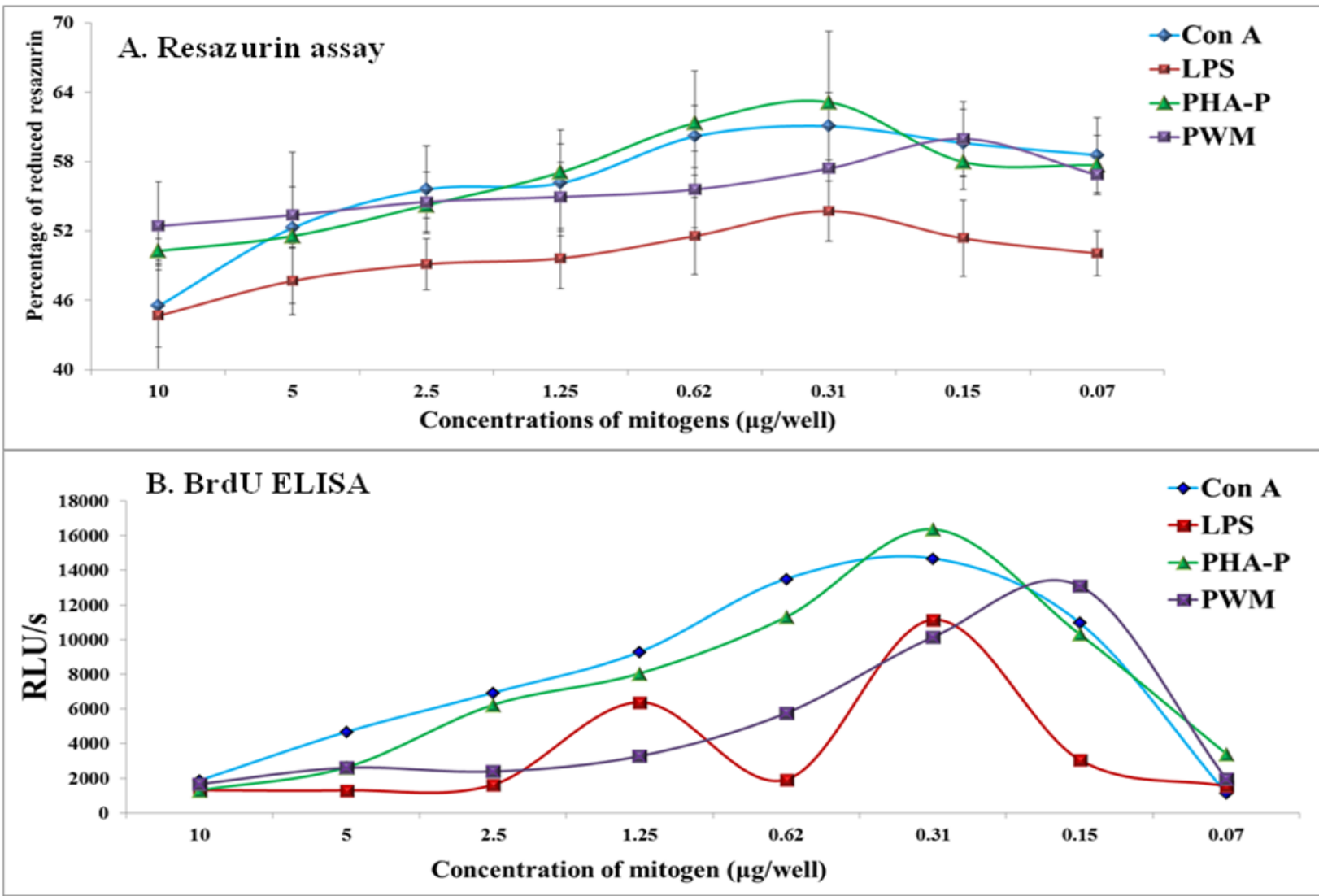

Fig.3 Proliferation of goat PBMCs stimulated with different mitogens. A. Resazurin assay and B) BrdU ELISA 
In our study, Histopaque 1.083 yielded $\sim 10$ times more cell yield than 1.077. Most of the researchers used Histopaque 1.077 for the separation of human PBMCs. It was suggested that Histopaque 1.083 may be used for rats, mice, and other mammals (McCarthy, 2007).

For the isolation of rabbit PBMCs, it was reported that 1.083 gradient medium yielded a higher recovery rate and purity than 1.077 (Feldman and Mogelesky, 1987). Our study indicates that resazurin dye-based cell proliferation assay is comparable to BrdU ELISA and can be used for both goat and sheep PBMCs.

Culture medium, density gradient and other conditions will influence the growth and proliferation rate of $\mathrm{PBMCs}$ and the assay needs to be optimized for different cells or species. To the best of our knowledge, this is the first resazurin based assay for assessing cell proliferation for both goats and sheep.

\section{Acknowledgments}

The research work was supported by grants received from CAAST-ACLH (NAHEP/CAAST/2018-19) of ICAR-World Bank-funded National Agricultural Higher Education Project (NAHEP) and ICAR-IVRI.

\section{References}

Aslantürk, Ö.S., 2018. In Vitro Cytotoxicity and Cell Viability Assays: Principles, Advantages, and Disadvantages, in: Larramendy, M.L., Soloneski, S. (Eds.), Genotoxicity - A Predictable Risk to Our Actual World. InTech. https://doi.org/10.5772/intechopen.71923

Bhanuprakash, V., Indrani, B.K., Hegde, R., Kumar, M.M., Moorthy, A.R.S., 2004. A classical live attenuated vaccine for sheep pox. Trop Anim Health Prod 36,
307-320.

Borra, R.C., Lotufo, M.A., Gagioti, S.M., Barros, F. de M., Andrade, P.M., 2009. A simple method to measure cell viability in proliferation and cytotoxicity assays. Braz Oral Res 23, 255-262.

Brown, J., 1977. A micro-method for the study of in vitro lymphocyte transformation to specific antigens. J. Immunol. Methods 18, 17-32.

Chan, S.S.M., McConnell, I., Blacklaws, B.A., 2002. Generation and characterization of ovine dendritic cells derived from peripheral blood monocytes. Immunology 107, 366-372.

Chaplin, D.D., 2010. Overview of the immune response. J. Allergy Clin. Immunol. 125, S3-23. https://doi.org/10.1016/j.jaci.2009.12.980

Click, R.E., 2014. Review: 2-mercaptoethanol alteration of in vitro immune functions of species other than murine. J. Immunol. Methods 402, 1-8. https://doi.org/10.1016/j.jim.2013.11.007

Czekanska, E.M., 2011. Assessment of cell proliferation with resazurin-based fluorescent dye. Methods Mol. Biol. 740 , 27-32. https://doi.org/10.1007/978-1-61779108-6_5

Duque, A., Rakic, P., 2011. Different effects of bromodeoxyuridine and $[3 \mathrm{H}]$ thymidine incorporation into DNA on cell proliferation, position, and fate. J. Neurosci. 31, 15205-15217. https://doi.org/10.1523/JNEUROSCI.30 92-11.2011

Feldman, D.L., Mogelesky, T.C., 1987. Use of Histopaque for isolating mononuclear cells from rabbit blood. J. Immunol. Methods 102, 243-249. https://doi.org/10.1016/00221759(87)90083-4

Fiscus, S.A., DeMartini, J.C., Pearson, L.D., 1982. Variation in mitogen-induced ovine 
lymphocyte blastogenesis: adherent cells or 2-mercaptoethanol restore randomly depressed responses. Vet. Immunol. Immunopathol. 3, 345-359.

Gottshall, S.L., Hansen, P.J., 1994. Enhancement of mitogen-induced lymphocyte proliferation in sheep. Zentralblatt Veterinarmedizin Reihe B 41, 541-547.

Hans, F., Dimitrov, S., 2001. Histone H3 phosphorylation and cell division. Oncogene 20, 3021-3027. https://doi.org/10.1038/sj.onc.1204326

Huang, J., Zhu, X., Wang, H., Han, S., Liu, L., Xie, Y., Chen, D., Zhang, Q., Zhang, L., Hu, Y., 2017. Role of gambogic acid and NaI131 in A549/DDP cells. Oncol Lett 13, 37-44. https://doi.org/10.3892/ol.2016.5435

Koyanagi, M., Kawakabe, S., Arimura, Y., 2016. A comparative study of colorimetric cell proliferation assays in immune cells. Cytotechnology 68, 1489-1498.

https://doi.org/10.1007/s10616-0159909-2

Kuwagata, M., Ogawa, T., Nagata, T., Shioda, S., 2007. The evaluation of early embryonic neurogenesis after exposure to the genotoxic agent 5-bromo-2'deoxyuridine in mice. Neuro toxicology 28,780-789.

https://doi.org/10.1016/j.neuro.2006.07.0 17

McCarthy, D.A., 2007. Cell Preparation, in: M.G., M. (Ed.), Flow Cytometry: Principles and Applications. Humana Press, Totowa, New Jersey, pp. 17-58.

Mosmann, T., 1983. Rapid colorimetric assay for cellular growth and survival: application to proliferation and cytotoxicity assays. J. Immunol. Methods 65, 55-63.

Nikbakht, M., Pakbin, B., Nikbakht Brujeni, G., 2019. Evaluation of a new lymphocyte proliferation assay based on cyclic voltammetry; an alternative method. Sci Rep 9, 4503. https://doi.org/10.1038/s41598-01941171-8

Norian, R., Delirezh, N., Azadmehr, A., 2015. Evaluation of proliferation and cytokines production by mitogenstimulated bovine peripheral blood mononuclear cells. Vet Res Forum 6, 265-271.

Patel, H.D., Zaveri, A.D., Zaveri, D.N., Shah, S., Solanki, A., 2013. Comparison of the MTT and alamar blue assay forin vitro anti cancer activity by testing of various chalcome and thiosemicarbazone derivatives. Int $\mathrm{J}$ Pharm Bio Sci 4, 707-716.

Quah, B.J.C., Parish, C.R., 2012. New and improved methods for measuring lymphocyte proliferation in vitro and in vivo using CFSE-like fluorescent dyes. J. Immunol. Methods 379, 1-14. https://doi.org/10.1016/j.jim.2012.02.012

Riss, T.L., Moravec, R.A., Niles, A.L., Duellman, S., Benink, H.A., Worzella, T.J., Minor, L., 2004. Cell Viability Assays, in: Sittampalam, G.S., Grossman, A., Brimacombe, K., Arkin, M., Auld, D., Austin, C.P., Baell, J., Bejcek, B., Caaveiro, J.M.M., Chung, T.D.Y., Coussens, N.P., Dahlin, J.L., Devanaryan, V., Foley, T.L., Glicksman, M., Hall, M.D., Haas, J.V., Hoare, S.R.J., Inglese, J., Iversen, P.W., Kahl, S.D., Kales, S.C., Kirshner, S., Lal-Nag, M., Li, Z., McGee, J., McManus, O., Riss, T., Saradjian, P., Trask, O.J., Weidner, J.R., Wildey, M.J., Xia, M., Xu, X. (Eds.), Assay Guidance Manual. Eli Lilly \& Company and the National Center for Advancing Translational Sciences, Bethesda (MD).

Roehm, N.W., Rodgers, G.H., Hatfield, S.M., Glasebrook, A.L., 1991. An improved colorimetric assay for cell proliferation and viability utilizing the tetrazolium 
salt XTT. J. Immunol. Methods 142, 257-265.

Romar, G.A., Kupper, T.S., Divito, S.J., 2016. Research Techniques Made Simple: Techniques to Assess Cell Proliferation. Journal of Investigative Dermatology 136, e1-e7. https://doi.org/10.1016/j.jid.2015.11.02 0

Sandbulte, M.R., Roth, J.A., 2004. Methods for analysis of cell-mediated immunity in domestic animal species. J. Am. Vet. Med. Assoc. 225, 522-530.

Schultz, R.D., 1982. Assays of cellular immunity. J. Am. Vet. Med. Assoc. 181, 1169-1176.

Singh, S., Pathak, A.K., Sharma, R.K., Khan, M., 2015. Effect of tanniferous leaf meal based multi-nutrient blocks on feed intake, hematological profile, immune response, and body weight changes in Haemonchus contortus infected goats. Vet World 8, 572-579. https://doi.org/10.14202/vetworld.2015. $572-579$

Strober, W., 2001. Trypan blue exclusion test of cell viability. Curr Protoc Immunol
Appendix 3, Appendix 3B. https://doi.org/10.1002/0471142735.ima 03bs 21

Sylvester, P.W., 2011. Optimization of the tetrazolium dye (MTT) colorimetric assay for cellular growth and viability. Methods Mol. Biol. 716, 157-168. https://doi.org/10.1007/978-1-61779012-6_9

Vega-Avila, E., Pugsley, M.K., 2011. An overview of colorimetric assay methods used to assess survival or proliferation of mammalian cells. Proc. West. Pharmacol. Soc. 54, 10-14.

Wing, E.J., Remington, J.S., 1977. Cellmediated immunity and its role in resistance to infection. West. J. Med. 126, 14-31.

Zhi-Jun, Y., Sriranganathan, N., Vaught, T., Arastu, S.K., Ahmed, S.A., 1997. A dye-based lymphocyte proliferation assay that permits multiple immunological analyses: mRNA, cytogenetic, apoptosis, and immunophenotyping studies. J. Immunol. Methods 210, 25-39.

\section{How to cite this article:}

Soumajit Sarkar, Ashwini Rameshrao Chaple, Aruna Kuniyal, Dhanavelu Muthuchelvan, Muthannan Andavar Ramakrishnan. 2020. Resazurin Based Colorimetric Proliferation Assay for PBMCS of Goats and Sheep. Int.J.Curr.Microbiol.App.Sci. 9(02): 967-975. doi: https://doi.org/10.20546/ijcmas.2020.902.113 